\title{
Job Satisfaction among Women Working in Night Shift in Chennai City
}

\author{
A. Anuradha
}

\begin{abstract}
Women are the backbone of any economy primarily shaping way forward for the country. She earlier stayed at her house to attend her domestic duties is currently maintaining work and residential at the same time, collaborating within the method of economic development on associate equal footing with men. The Government of India, meeting a long demand for gender parity within the men, has approved associate change within the Factories Act 1948 to permit lady staff to work in nightshifts. The change suggests that nightshift for girls shall be allowed on condition that the leader ensures safety; adequate safeguards within the manufactory as regards activity safety and health, civil rights for girls employees, required safeguard of their noble, integrity and conveyance from the manufactory premises to the closest purpose of their residence are met. The study is a shot to search out the impact nightshifts has on girls and therefore the opportunities for growth that are offered them by the varied sectors.
\end{abstract}

Keywords: Directive principles, Legislature, Workforce.

\section{INTRODUCTION}

$\mathrm{N}_{\text {ight }}$ shifts normally counsel with working hours between 7:00 p.m. to 6:00 a.m. In India, enactments simply like the Plantation Labor Act, 1951, Factories Act, 1948, State retailers and foundations Act, and so forth contained arrangements recommending work all through night for women. Today, when a ton of exchange, the boycott has been brought up in lion's share of businesses. for instance, the Factories Act, 1948, that toward the beginning disallowed young ladies from working in night shifts, at present changed ladies to figure at their ideal worldly request. The arrangements, underneath this demonstration, were changed in light of the fact that the get together and legal executive opined that such confinements hamper rudimentary Rights of balance in possibility and opportunity of development and conjointly appropriate to figure as requested down in Directive Principles of the State Policy. This move by gathering defied a few protests from people with standard convictions anyway was incredibly valued by the advanced society.

Safe transportation for ladies keeps on remaining a huge test inside the BPO and focus exchange. Following numerous episodes of violations against young ladies BPO staff, a few BPO firms have fixed their security arrangements.

Revised Manuscript Received on December 05, 2019.

* Correspondence Author

Dr. A. Anuradha*, HOD , Department of Commerce, MGR University, Chennai, India. E-mail: pandian.kkdi@gmail.com
Organization supported get and drop vehicles are accommodated young ladies staff. a few organization principles stipulate that young ladies should travel exclusively inside the nearness of another male specialist. Inside hotlines and SMS administrations are acquainted with watch the prosperity of voyaging staff. Satisfactory historical verifications on the chose taxi drivers likewise are made by the businesses. These measures have improved the case fundamentally, despite the fact that regardless it doesn't fabricate the women staff feel 100 percent safe, especially once they include night shifts. The socio-social factors conjointly neutralize the women UN office are used with BPO and choice focuses in Indian country. In spite of the fact that the woman is upbeat and happy together with her night obligation work, and is getting an awesome compensation for it, anyway her issues could start once she gets hitched. In a few cases the women are compelled to stop their employments because of the objection to the spouse and his family. In any case, the BPO exchange is making a shot to deal with this side comparably.

\section{STATEMENT OF THE PROBLEM}

The economic dip and slow growth in year 2009-10 might be a legitimate reason for non-hike of earnings for women operating in numerous sectors. A lot of competitors in BPO, Hospital , IT industry's and increase in additional job-seekers and many new graduates significantly women section to work in night shifts extremely impact the expansion of existing girls staff operating for over five years. The women operating in night shifts face security issues, travelling issues and social evils a lot of operating hours in night extremely affects their health to nice extent. They bear mental harassments thanks to improper balance of work-personal life they may not stayed to worry their oldsters or husband or children's health and studies.

\section{REVIEW OF LITERATURE}

Marta Mas (2016) in his paper explored the connection between work-life balance, structure pride and job satisfaction. once evaluating worker work-life balance the current paper takes into thought 2 relevant antecedents: supervisor support and job autonomy; and explores their link with structure pride and job satisfaction. To verify the hypothesis, a form survey was wont to collect information 
during a Spanish pharmaceutical organization; 374 responses were obtained. Structural equation modeling was used for the information analysis. information confirms the connection between the analyzed constructs.

The results support the hypothesized relationships of supervisor work-life balance support and autonomy with worker work-life balance. additionally, worker work-life balance is completely connected with structure pride and job satisfaction. This study provides a helpful activity model that employers and staff will use to judge and improve work-life balance through job autonomy and supervisor support. firms ought to concentrate to worker work-life balance to reinforce structure pride and job satisfaction. The analysis tries to assist firms to additional effectively use their human capital resources. The paper addresses gaps within the current literature in work-life, structure pride and job satisfaction. The results could function the standards for managers to higher enhance worker job satisfaction in organizations.

Marta Mas (2016) in his paper investigated the association between work-life balance, structure pride and employment fulfillment. once assessing specialist work-life balance. he present paper takes into idea 2 significant predecessors: administrator backing and occupation self-sufficiency; and investigates their connection with structure pride and employment fulfillment. To confirm the theory, a structure overview was wont to gather data during a Spanish pharmaceutical association; 374 samples were obtained. Auxiliary condition displaying was utilized for the data examination. Data affirms the association between the investigated develops. The outcomes bolster the estimated connections of chief work-life offset backing and self-sufficiency with specialist work-life balance. Further more, laborer work-life offset is totally associated with structure pride and occupation fulfillment. This investigation gives an accommodating action model that businesses and staff will use to pass judgment and improve work-life balance through occupation independence and manager support. firms should think to specialist work-life equalization to strengthen structure pride and occupation fulfillment. The examination attempts to help firms to extra successfully utilize their human capital assets. The paper tends to holes inside the present writing in work-life, structure pride and occupation fulfillment. The outcomes could work the guidelines for administrators to higher upgrade laborer work fulfillment in associations.

Rupashree (2010) analyzed the job of work-family enhancement inside the connections between structure mediations for work-life balance (work qualities, work-life preferences and arrangements, chief help and work-family culture) and employment results. It's estimated that structure intercessions for work-life parity will be totally connected with occupation results and work to family enhancement can intervene these connections. Information were gathered from 216 social control laborers through an organized structure from four associations in Asian country speaking to creating and information innovation (IT) areas. Investigation was done exploitation numerous relapses. Employment attributes were completely connected with every one of the proportions of occupation results. Manager backing and work-family culture were totally connected with occupation fulfillment and enthusiastic duty. No significant affiliation was found between work life focal points and approaches (WLBPs) and any of the obligation result measures. Occupation attributes and manager backing were completely connected with work-to-family improvement. Work-to-family advancement intervene the connections between occupation qualities and each one activity results and between manager support and passionate responsibility. The correspondence style anticipates ends in regards to connection. The discoveries have suggestions for thinking of occupations, creating confirm work-family culture and overseeing laborer work-family interface for expanding individual and structure results. The examination reflected on the work-family space connections in a novel socio-cultural setting and incontestable the interceding job of work family advancement inside the connections between structure mediations for work-life parity and occupation results.

\section{OBJECTIVES OF THE STUDY}

- To study the opinion regarding complacency towards their job among women employees.

- To give suggestions to increase the satisfaction level based on the data collected.

- To find out the issues faced by women's working in night shift in various sectors like Information Technology and Information technology enabled services, Textile, Manufacturing, Hospital and Flight services.

\section{RESEARCH METHODOLOGY}

\section{A. Research Design}

The research design used for the study is Descriptive research design and the respondent has chosen women working in various industry's like hospital, IT/ITES, Textiles, Manufacturing, flight services in Chennai constitute the universe for study.

\section{B. Sampling}

HCL technologies Limited, Vadapalani, Unit (IT/ITES unit) and Apollo Hospital, Greams road, (Hospital/health Services). Ambattur clothing limited,Ambattur (Textiles units), Air Deccan, Chennai (Flight services), Ambattur Heat Treaters Private Limited, Ambattur (Manufacturing unit) in Chennai city. The sample selected for the study is 250 which is 50 from each category and it is taken randomly which is simple random method.

\section{FINDINGS}

- It is found that $80 \%$ respondents from IT/ITES, $60 \%$ respondents from textile and manufacturing, $20 \%$ respondents from hospital sector, $86 \%$ respondents from

Published By:
Published By: Engineering \& Sciences Publication 
flight services are aged between 20-30 years. It is found that $20 \%$ respondents from IT/ITES, $36 \%$ respondents from textile and manufacturing industry, $70 \%$ respondents from hospital services, $14 \%$ respondents from flight services are aged between $31-40$ years. $10 \%$ respondents in hospital industry are aged above 50 years. It is found that $54 \%$ respondents from IT/ITES, $80 \%$ respondents from textile industry, $70 \%$ respondents from manufacturing industry, $40 \%$ respondents from hospital sector and $20 \%$ respondents from flight services are married. It is found that $46 \%$ respondents from IT/ITES, $20 \%$ respondents from textile industry, $30 \%$ respondents from manufacturing industry, 60\% respondents from hospital sector and $80 \%$ respondents from flight services are unmarried.

- It is found that majority of the respondents in IT/ITES and manufacturing industry $(60 \% \& 50 \%$ respectively) are always able to cope up with their family demands while working in night shifts. But, $20 \%$ respondents of Textile industry, $14 \%$ in hospital sector and $34 \%$ in flight service are 'Not at all' able to cope with their family demands while working in night shifts.

- There is no significant relationship between age and health problem because of working in night shift

- There is significant relationship between type of organization and overall satisfaction with the job. It is found the many women working in textile industry do not have overall satisfaction with their job, when compared with women in other sectors.

\section{RECOMMENDATIONS}

- Doctors must be available during night hours for working women in order to provide immediate assistance to health problems among the women working in night shifts which may reduce their stress.

- The organisation should ensure proper safety measures for the women working in night shifts. Proper lighting, sanitation, protective equipments and dresses have to provide to night shifts employees and maintain good environment for job security among the employees. The inspector of factories and concerned authorities should monitor the safety measures and work environment provide for women employees working in night shifts

- The organisation should follow proper rewarding system for the best employee and must motivate them by monetary and non-monetary benefits to built confidence towards their profession and loyalty towards their company

- Many organisation do not have proper grievance cell to resolve problems existing among women employees working in night shifts regarding their work, health, family, peer and other work related issues. Proper counseling department can be established for women providing proper guidance and assistance to women in taking right decision in their work and personal life. The management has to assist the women employees in their work and career development to motivate the women employees

\section{CONCLUSION}

The research work on job satisfaction among women working in night shifts in various industries was very useful for the researcher to find the satisfaction level among the women employees working in night shifts in various industries and problems faced by them in their personal and work life. Thus the research finds that the social status and plight of working conditions of women working in night shift has to improve drastically particularly in major sector like textile, manufacturing industries which are the back bone of Indian economy.

\section{REFERENCES}

1. Baral, R., \& Bhargava, S. (2010). Work-family enrichment as a mediator between organizational interventions for work-life balance and job outcomes. Journal of managerial psychology, 25(3), 274-300.

2. Kothari C.R. 'Research Methodology' Revised 2nd Edition, New Age International (P) Ltd., Publishers.

3. Mas-Machuca, M., Berbegal-Mirabent, J., \& Alegre, I. (2016). Work-life balance and its relationship with organizational pride and job satisfaction. Journal of Managerial Psychology, 31(2), 586-602.

4. Thampi. D.S (2006) 'Strategic Approach to Women working in night shifts in India' Atlantic Publishers and Distributors, New Delhi.

5. Sunitha menon.R (2006) "Coping strategies for women working in night shifts”. New age international publishers, New Delhi.

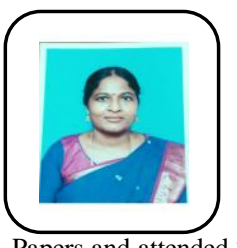

\section{AUTHOR PROFILE}

Dr. A. Anuradha, MCS, MBA, M.Phil, Ph.D have 20 years service in Education and Head of the Department of Commerce in Dr.M.G.R Educational \& Research Institute, Deemed to be University, Maduravoyal Chennai - 600095, published 20 International Research Papers and attended 20 International Conference and 50 National Conference and got Best Teacher Award In 2016. I made Syllabus \& Curriculum for nearly 12 Program (UG \& PG). 